\title{
Impacts of regional energy markets on decentralised energy supply
}

\author{
Jens MAIWALD, Tino SCHÜTTE \\ University of Applied Sciences Zittau/Görlitz, Germany
}

\begin{abstract}
:
Aim: This paper aims to describe an approach to develop a simulation model for investigating regional energy markets. Therefore the so called Cellular Approach is combined with the approach of AgentBased Modelling.

Design / Research methods: The model is built as a bottom-up approach for integral load management. Thus, supply factors such as limitations in generation are integrated directly and display flexibility. Thereby each market participant has its own economic interest. By the use of specific behaviour patterns and learning effects each agent in the model can act individually. This enables the market model to simulate how actors behave in changing situations.
\end{abstract}

Conclusions / findings: The model shown in this paper provides an alternative to considerations of energy supply systems via equation-based optimization models. The combination of these two approaches enhances to observe two central aspects of the German energy turnaround, decentralisation and the consumers changing role at the energy market.

Originality / value of the article: The Cellular Approach offers potential benefits for integrating renewable energy sources in regional power supply. Often discussed on a technical level, this paper focuses on the economical side of this topic. Moreover, differing to other research activities usually using optimization techniques, an Agent-Based Model is formulated to simulate a regional energy market. In the combination of a supply system primarily based on renewable energy sources and enhanced with different types of energy storage it is possible to simulate a supply system of the future.

Keywords: Energy Markets, Renewable Energy Sources, Agent-based Modelling, Cellular Approach JEL: P18, P28, Q41, Q42

Contact: Jens Maiwald, Hochschule Zittau/Goerlitz - University of Applied Sciences, Faculty of Business Administration and Engineering, Theodor-Koerner-Allee 16, 02763 Zittau. E-mail: jens.maiwald@hszg.de.

Received: 05-01-2018, Revised: 16-05-2018, Accepted: 01-05-2018

doi: http://dx.doi.org/10.29015/cerem.654 


\section{Problem description}

\subsection{Brief overview of the German electricity system}

Caused by the Energiewende (energy turnaround) the German energy supply system is subjected to tremendously alterations which will affect all market participants and their behaviour. Forced by the German government the share of renewable energy sources (RES) in electricity consumption should be $80 \%$ until 2050. Consequentially this will push conventional power plants out of the market by law over the upcoming years. Furthermore, this omission means a loss of secured capacity for the German supply system which will be substituted by more and more RES.

Key technologies for substituting conventionals will be photovoltaic (PV) and wind power (WP). Today about $60 \%$ of the electricity generated from RES are from PV (20\%) and WP (43\%) (AGEB 2016; BMWi 2016: 9 f). A big issue is the fluctuating feed-in of these power plants. Solar radiation and wind intensity are given by nature and not controllable in any way. Due to high quality forecasts, operators are able to utilise the given potentials at the best possible rate. Nevertheless, the share of PV and wind power in overall installed capacity in Germany is $21 \%$ respectively $24 \%$. In fact the share in electricity generation is just $7 \%$ respectively $15 \%$ (Fraunhofer ISE 2017; Fraunhofer ISE 2016). This fact clearly shows the dependence on certain weather conditions.

\subsection{Electricity prices}

Bląd! Nie można odnaleźć źródla odwolania. shows the development of average electricity prices on EPEX spot market and for private households (HH) in Germany over the last seven years. What hits the eye first are the opposed trends of these graphs. While prices on spot marked dropped by $2.13 \mathrm{ct} / \mathrm{kWh}$ prices for $\mathrm{HH}$ increased by $6.73 \mathrm{ct} / \mathrm{kWh}$. 
Figure 1. Electricity prices on EPEX spot market (left) and for households (right) [ct/kWh]
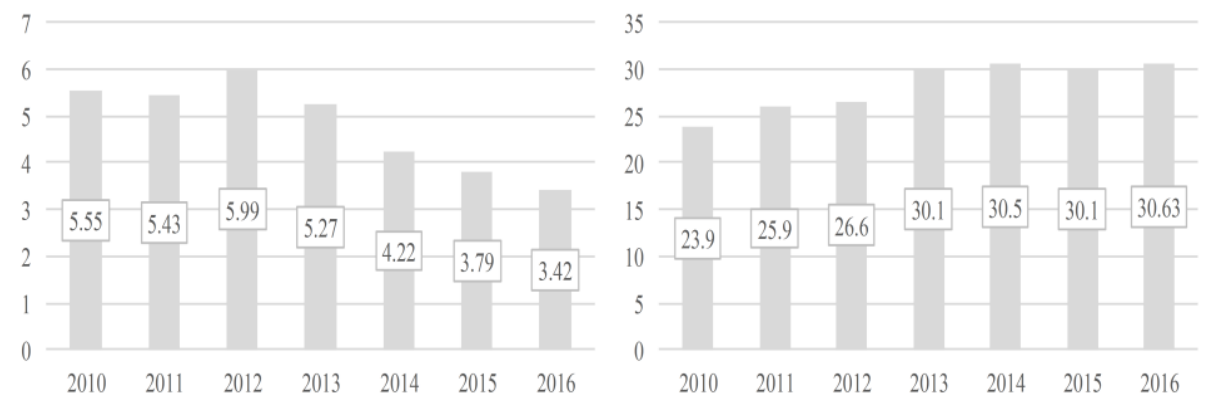

Source: Authors' own elaboration, Data Source: BMWi 2015: 74; Bundesnetzagentur,

Bundeskartellamt 2016: 212

\section{Figure 2. Merit-Order-Effect}

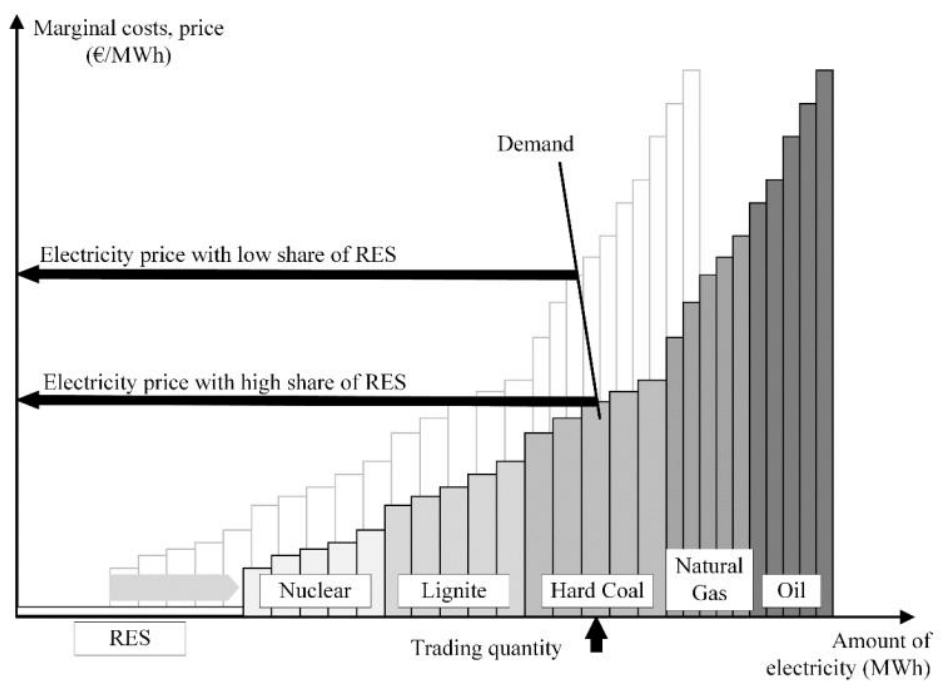

Source: Authors' own elaboration

Spot market prices decrease because of the merit-order-effect. The merit order is an ascending order of marginal costs from all power plants that are offering to generate a certain amount of electricity. The marginal costs of the last power plant that is needed to fulfil the demand reflect the market clearing price for electricity. RES especially solar, wind and even water are characterized by relative high 
investment costs but low marginal costs close to zero. As a result increasing shares of RES effect a shift to the right of the merit order (see ).

Electricity prices for $\mathrm{HH}$ consist of three main components that are affected differently, as shown in table 1 . Whereas the average costs for generation and sales decreased, the average costs for grid fee and metering increased but both in a slightly manner. The big increase in $\mathrm{HH}$ electricity prices mainly results from the third price component taxes, levies, and apportionments including the so-called EEG-apportionment. This apportionment goes back to the German Renewable Energy Sources Act (EEG) and is part of the fixed feed-in EEG-remuneration which was intended as an initial funding for compensating cost benefits from conventional power plants over RES. ${ }^{1}$ Over the last seven years this apportionment increased from 2.05 to $6.354 \mathrm{ct} / \mathrm{kWh}$ (BDEW 2016: $7 \mathrm{f}$ ) because of higher shares of RES.

Table 1. Components of household electricity prices [ct/kWh]

\begin{tabular}{|l|r|r|r|}
\hline & Generation & Grid fee & Taxes, levies \\
\hline $\mathbf{2 0 1 0}$ & 8.16 & 5.86 & 9.67 \\
\hline $\mathbf{2 0 1 6}$ & 6.11 & 7.07 & 15.51 \\
\hline
\end{tabular}

Source: Authors' own elaboration, Data Source: BDEW 2016: 11

\subsection{Profitability of RES electricity}

In comparison to conventional power plants renewables own relative high levelized costs of electricity (LCOE). ${ }^{2}$ At the energy exchange the obtainable contribution margin results from the difference between electricity price and marginal costs of the particular asset. As marginal costs of RES are close to zero the contribution margin is almost equal to the electricity price and reflects the whole earnings of the particular asset. In other words, the achieved electricity price can be entirely used to cover the LCOE.

${ }^{1}$ The EEG-remuneration is paid to operators of RES power plants. The remuneration is a fixed amount which is financed by two parts. The first part are earnings from selling electricity at the energy exchange. The difference between the amount of remuneration and earnings is compensated by the EEG-apportionment which is paid by the consumers.

${ }^{2}$ LCOE are calculated as the net present value of all costs over the lifetime of the power plant divided by its total electrical energy output. 
The approach of LCOE as a long-term consideration reflects the costs respectively the earnings which has to be obtained over the useful life of the asset on average. In short-term considerations earnings could fall below this limit.

As it is depicted in a high share of renewables leads to a drop of the electricity price at the energy exchange causing a smaller contribution margin for all market participants. Today a cost-covering operation at the market (without promotion) is mainly not feasible for RES. Only a few hours per year with high price peaks enable profitable business.

Table 2 shows the average price of electricity at the Day-Ahead Market in comparison to the minimum and maximum LCOE of PV and wind (onshore).

Table 2. Day-Ahead electricity prices and LCOE of RES

\begin{tabular}{|c|c|c|c|c|}
\hline \multicolumn{5}{|c|}{ Electricity price Day-Ahead [ct/kWh] } \\
\hline & Min & Average & Max \\
\hline Summer & 0.065 & 3.204 & 5.695 \\
\hline Winter & 2.883 & 5.341 & 16.352 \\
\hline \multicolumn{5}{|c|}{ LCOE of RES [ct/kWh] } \\
\hline PV & Min & 6.9 & Max & 12.8 \\
\hline Wind (onshore) & Min & 5.2 & Max & 9.1 \\
\hline
\end{tabular}

Source: Authors' own elaboration, Data Source: KFW 2016: 1; Use My Energy 2017

Recent incidents on the market show the evolution of costs for RES and give a contrary but promising picture. Since 2017 the Federal Network Agency issues tenders (pay as bid) to determine the amount of promotion for new assets. ${ }^{3}$ The operators bid on a fixed value they want to earn at the energy exchange. This highly competitive approach leads to a massive RES cost degression. Table 3 displays the results of the last two tendering procedures of PV and wind onshore. In comparison to

table 2 the results show that under certain conditions the operation of onshore wind assets can be competitive at market prices and that the operation of open-site PV systems at least tend to become competitive at market prices. ${ }^{4}$

\footnotetext{
${ }^{3}$ For further information see chapter '1.4 Marketing of electricity out of RES'.

${ }^{4}$ The tendering for wind offshore yield that operation of these assets is feasible without any kind of promotion under certain conditions.
} 
Table 3. Results of tendering procedures 2017

\begin{tabular}{|r|r|r|r|r|}
\hline & \multicolumn{2}{|c|}{ PV biddings } & \multicolumn{2}{c|}{ Wind (onshore) biddings } \\
\hline Month & June & October & July & November \\
\hline Volume & $200 \mathrm{~kW}$ & $200 \mathrm{~kW}$ & $1013 \mathrm{MW}$ & $1000 \mathrm{MW}$ \\
\hline Lowest bidding & $5.34 \mathrm{ct} / \mathrm{kWh}$ & $4.29 \mathrm{ct} / \mathrm{kWh}$ & $3.50 \mathrm{ct} / \mathrm{kWh}$ & $2.20 \mathrm{ct} / \mathrm{kWh}$ \\
\hline Highest bidding & $5.90 \mathrm{ct} / \mathrm{kWh}$ & $5.06 \mathrm{ct} / \mathrm{kWh}$ & $4.29 \mathrm{ct} / \mathrm{kWh}$ & $3.82 \mathrm{ct} / \mathrm{kWh}$ \\
\hline $\begin{array}{r}\text { Volume-weighted } \\
\text { average }\end{array}$ & $5.66 \mathrm{ct} / \mathrm{kWh}$ & $4.91 \mathrm{ct} / \mathrm{kWh}$ & $4.28 \mathrm{ct} / \mathrm{kWh}$ & $3.82 \mathrm{ct} / \mathrm{kWh}$ \\
& & & & \\
\hline
\end{tabular}

Source: Authors' own elaboration, Data Source: Bundesnetzagentur 2017

Considering the merit order, (see ) it is probable that the obtained contribution margin of renewables could increase in future years. Plausible reasons for this have a regulatory background, like increasing marginal costs of conventional power plants because of increasing prices of $\mathrm{CO}_{2}$ emission certificates and the phase out of nuclear power plants until 2022 what will have an increasing impact on electricity prices. Besides this decreasing investment costs for RES power plants will have a further beneficial effect on cost recovery. Not proven right now is in which way fuel costs for conventional power plants will change. Nevertheless, several literatures do not clearly state whether the expectable spread will be fully cost-covering or not. The long-term prediction of energy pricing is very insecure. Thus, no exorbitantly increasing or decreasing electricity prices can be assumed.

\subsection{Marketing of electricity out of RES}

The perhaps most distressing issue within the Energiewende concerns the selffinancing of RES in a long-term view. Today there are two main possibilities for selling electricity out of RES-based power plants over the EEG. The first one is via fixed feed-in remuneration, what means that the operator gets a fixed amount of money for each $\mathrm{kWh}$ of electricity depending on the year of commissioning of the power plant guaranteed for the next 20 years. Furthermore, the Transmission System Operator (TSO) has the duty to purchase the whole amount of electricity. The level of the remuneration is decreasing over the next years and phases out. This fact will influence future investment decisions negatively. 
The second possibility is a direct marketing. Thereby the power plant operator sells the generated electricity directly on the energy exchange. However, because of the low market prices this alone would not be as economically attractive as the fixed feed-in remuneration today. Therefore, a market premium is granted to the operator to compensate the difference between the fixed feed-in remuneration (in the year of commissioning) and the monthly average market price. As this approach allocates the amount of earnings to the value of the fixed feed-in remuneration, the earnings will decrease as the fixed feed-in phases out. To recoup the higher organizational effort of this marketing strategy a management premium is granted in addition. Especially because of the opportunity to take advantage of price peaks at the energy exchange direct marketing is nowadays chosen more and more.

As mentioned above the Federal Network Agency now issues tenders to determine the market premium for new assets. Thus, the allocation is no longer connected to statutory remunerations it is bounded to market competition. The bidding is axiomatic and includes the whole earnings operators want to obtain. In other words the amount of the market premium depends on the monthly average electricity price (see figure 3 ).

\section{Figure 3. Dependency of market premium on electricity price}

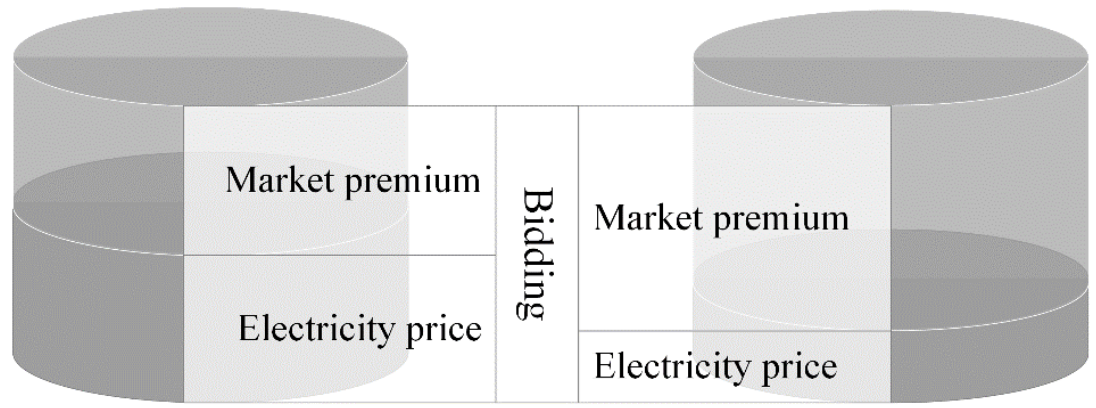

High electricity price Low electricity price

Source: Authors' own elaboration 


\section{Modelling regional electricity supply and demand}

\subsection{Current challenges}

As written in the former chapters, there are two main problems. First, consumers bear the biggest part of the financial burden of the Energiewende; however, they are not able to benefit directly from decreasing prices at the energy exchange. On the other hand, most of the existing RES assets are not able to operate cost covering without promotion in a long-term view, what strains the consumers in the end. A further open question that touches the above presented issues is how to deal with the increasing decentralisation in energy generation and the resulting necessity for grid expansion.

This research aims to examine the importance of regional energy markets in the context of the Energiewende. The specific objective is to provide new insights whether regional energy markets deliver a valuable contribution for solving or at least mitigate the presented issues.

This paper presents the methodological approach taken for this study. It is a mixed methodology based on the so-called Cellular Approach (CA) for developing supply systems and the approach of Agent-Based Modelling (ABM) for simulating each market participants own economic interests.

\subsection{The Cellular Approach and Agent-Based Modelling}

The Cellular Approach as a method of endorsing decentralisation offers a broad range of potential benefits for integrating renewable energy sources in regional power supply and enhancing sustainability. Fundamental components in this approach are energy cells. Typical kinds are private households $(\mathrm{HH})$, trade, commerce and services (TCS), industry companies (IC) as well as traffic. Each cell has its own ability to supply, consume and store energy. All of these cells are connected among each other via energy grids and communication systems and build up superordinate energy cells in turn. The basic idea behind this approach is to equilibrate the generation and consumption of energy on the lowest possible level of these cellular structures (VDE 2015). 
Figure 4. Energy Cells

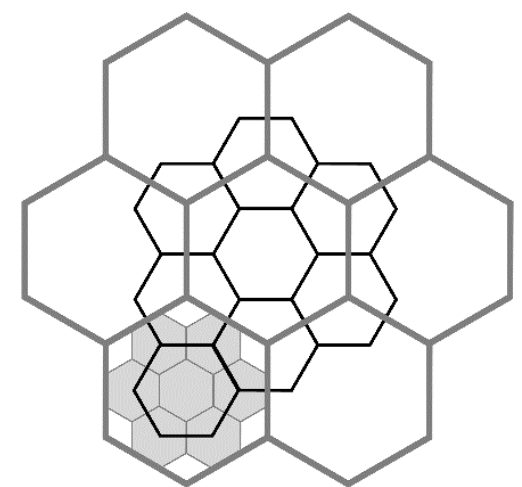

Source: Authors' own elaboration based on Kießling 2017

Referring to the VDE the CA can have a significant impact on the expansion respectively the upgrading of existing grids as well as on power plant new constructions concerning future energy sources. The study concludes: Autarkic supply of energy cells is only feasible for households and certain TCS whereas more energy-intensive cells like bigger TCS cells or industry necessarily need interconnection at least on a regional level (VDE 2015: 51). Based on this conclusions the CA covers the given issues in the introduction and represents a suitable framework for the further investigations.

The German electricity grid is sectioned in four different voltage levels (see table 4). As the highest voltage level is used to transport electricity over far distances, high, medium and low voltage levels are for the regional and local distribution of electricity. Assets based on RES are basically connected to the lower two voltage levels as well as the main part of the consuming entities HH, TCS, and IC. That means generation and consumption of electricity are mainly located on the same grid level. The CA connects all market participants on these voltage levels in a regional context. 
Table 4. Voltage levels of the German electricity grid

\begin{tabular}{|r|l|l|l|}
\hline $\begin{array}{r}\text { Voltage } \\
\text { Level }\end{array}$ & \multicolumn{1}{|c|}{ Purpose } & \multicolumn{1}{|c|}{ Generators } & \multicolumn{1}{c|}{ Consumers } \\
\hline $\begin{array}{r}\text { Highest voltage } \\
(380,220 \mathrm{kV})\end{array}$ & Transmission & $\begin{array}{l}\text { Coal, Nuclear, Pump- } \\
\text { Storage, Wind } \\
\text { (offshore) }\end{array}$ & $\begin{array}{l}\text { Downstream Distribution } \\
\text { System Operators (DSO) }\end{array}$ \\
\hline $\begin{array}{r}\text { High voltage } \\
(110 \mathrm{kV})\end{array}$ & $\begin{array}{l}\text { Regional } \\
\text { Distribution }\end{array}$ & Natural Gas, Water & Large IC \\
\hline $\begin{array}{r}\text { Medium } \\
\text { voltage }\end{array}$ & Local Distribution & $\begin{array}{l}\text { Wind (onshore), Solar } \\
\text { (parks), Biomass }\end{array}$ & General IC \\
\hline $\begin{array}{r}\text { Low voltage } \\
(230,400 \mathrm{~V})\end{array}$ & Local Distribution & Solar (roof) & HH, TCS \\
\hline
\end{tabular}

Source: Authors' own elaboration based on Nintzel 2016

For shedding light on the consumers impact on the energy market it is important to reproduce a broad range of individual interests and behaviour patterns. A key benefit of ABM is its ability to deal with heterogeneity (Hamill, Gilbert 2016: 30; Genoese 2010: 24). These models can portray an economic system in which orderly behaviour can emerge as a result of interaction between heterogeneous agents, none of whom has any understanding of how the overall system functions (Howitt 2012 in Hamill, Gilbert 2016). By this ABM is the most suitable instrument for dealing with the given issues in the description and the purpose of the model.

\section{The REM-model}

\subsection{Purpose of the model}

The following model description is inspired by the ODD (Overview, Design concepts, Details) protocol (Grimm et al. 2006).

The model is made for simulating the economical side of a future electricity supply system primarily based on RES. The focus is on inspecting a regional energy market and to examine its possible impacts on a sustainable decentralised energy supply. Supplementary the economic efficiency of plant operations plays a role to analyse the short-term as well as the long-term self-financing of RES-based electricity generation. 


\subsection{Entities and scales}

The models entities are geared to the main actors of a real energy supply system. The model covers the four major components: consumers, producers, grids, and storages.

The entities in the model representing the consuming sectors are HH, TCS, IC and storage systems. The e-mobility sector, furthermore, is modelled out of a system operators view. Therefore, it is treated as a storage system which is only able to store and consume energy, but not feed in back into the net in the first stage. The bidirectional load scenario for e-mobility will be a model extension.

For generating electricity out of RES PV, wind (onshore), biomass and water power plants are regarded in the model. Storage systems can act as a producer as well as a consumer, depending on its state of charge. Conventional power plants connected to the distribution grid are captured as separate producing entities.

The distribution grid is not regarded as an independent agent in the classical meaning. However, it plays a role as a connecting entity for the interconnection of consumers and producers. The transmission grid is also not reflected as an independent agent, but it is integrated as a single entity for gaining the opportunity of interregional load balance. Moreover the potential for generating electricity of large conventional power plants, like coal-fired or nuclear power plants, is implemented in the transmission grid entity too. Due to the fact that these assets are primarily connected to the transmission grid, they play a subordinate role in the bottom up modelling of a regional and decentralised energy market.

The model simulates the market in a one-hour resolution for a required time scale, for instance 8760 hours as described in this paper. Later on the model will be upgraded for investigations of the long-term effects covering several time horizons. This model will include additional facts such as changing fuel prices for conventional units, decreasing investment costs and technologically advanced constructions of RES power plants.

The term region means a defined distribution grid area. Thus, the biggest superordinate cell of the CA will be a distribution grid. Potential resulting edge problems of several entities located on the models edge can be countered by granting the opportunity of regarding the model as a sphere. 


\subsection{Model overview and design concepts}

The technical feasibility of the CA as the models basis is proven by a widely accepted technical study (VDE 2015). The model is built as a bottom-up model for integral load management. Thereby each market participant has its own economic interest. By the use of specific behaviour patterns and learning effects, each agent in the model can act individually.

The first period under review embraces a short-term time scale. Therefore, it is probable that consumers may change their behaviour slightly in the temporal aspect of electricity demand but not in the total amount of purchased electricity. In other words, the total amount of demanded electricity will remain steady for this time scale but the point in time when electricity is demanded from the net gets more flexible. The entities embodying storage systems will strengthen this behaviour. Thus, the overall electricity demand is set as one of the models major input parameters.

As shown in Table 1 the electricity price for consumers on the German energy market consists of three components. This modality is transferred to the model. The electricity price is embedded as a variable as it is described in the following. The first component, generation and sales, results similar to the day-ahead market and the merit order procedure. The second component, grid fee and metering, results from within the model. Therefore, the distance between the producing entity and the consumer is crucial. The further the distance, the higher the fee. The third component is assumed as a graduated variable covering taxes, levies, and apportionments claimed by the legislation. That means the higher the purchased amount of electricity, the lower gets the amount that has to be paid per $\mathrm{kWh}$. By this price mechanism, each consuming entity has its own individual price. Thus, each entity can decide by itself whether it wants to enhance its personal situation by changing its behaviour or not.

Besides this mechanism including a market-clearing price that is set at the energy exchange, peer to peer trading is also possible for the models entities. Each consuming entity is able to buy electricity as a kind of OTC transaction from generating entities. The price that has to be paid is negotiated between the entities, but as it is in reality this price will be orientated at the price at the exchange. 
The selling and buying entities have two main objectives: one quantitative and one monetary. Producers (sellers) want to gain as much profit as possible. That means they want to achieve a high utilisation of their power plants whenever the price is at least cost-covering. Differing the consumers (buyers) want to fulfil their demand for energy while spending a minimum of money. In conclusion, the quantitative objectives promote each other, whereas the monetary objectives oppose.

Additional to the issue of individual objectives some entities act with preferences. Producers are impartial. They do not prefer to whom they are selling the electricity as long as this entity is able to pay for it. However, consumers act quite different. The behaviour of HH and TCS entities depends on their personal rating of three criterions: (1) price, (2) energy source, (3) locality. That means for some of them the price of electricity matters the most. It does not matter where the power plant is located or from which energy source the electricity is generated. Others decide primarily by the energy source and secondarily by price and locality. Others prefer to be supplied by the local utility company, plus electricity price and RES. Hybrid forms of these preferences are also possible.

The preferences for consuming entities are set up as shown in table 5. For shortterm investigations the initial states for all consumer categories are the same and will vary later on.

Table 5. Preferences of consumers [\%]

\begin{tabular}{|r|c|c|c|}
\hline & Price & Source & Locality \\
\hline HH & 50 & 20 & 30 \\
\hline TCS & 70 & 20 & 10 \\
\hline IC & 90 & 5 & 5 \\
\hline
\end{tabular}

Source: Authors' own elaboration

For IC entities the crucial criterion is the price of electricity probably. Only a few IC entities would choose the supplier by energy source. Locality plays a minor role in their decisions. 


\subsection{Details of initialisation and input data}

A schematic overview of the models entities and their interdependencies is presented in figure 5 and figure $6 .{ }^{5}$ Further details are explained in the following.

The electricity consumption of the $\mathrm{HH}$ and the TCS sector is predefined as the German standard load profiles $H O$ and GO. As mentioned, the behaviour in consumption will not change significantly in short-term considerations but because of the ability to store energy temporally. The basic consumption of IC is not standardized in Germany. Therefore, an assumption of a small- to medium-sized IC in a two-shift operation is implemented in the model. ${ }^{6}$ Further, it is assumed that the IC entities can shift a certain share of their full capacity for a certain period. Both, share and time, are embedded as variables.

Some consuming entities are in control of their own small storage system. For short-term considerations it is assumed that these systems are primarily used for storing electricity while price drops. The state of charge of the small-scale storage systems is treated as $50 \%$ of their full capacity at the beginning of each simulation.

Additional to the small storage systems a major regional battery storage system, considered as one big battery power plant, is implemented. This battery storage is a separate entity of the model and can be used bidirectional. In other words, it can be used to store-in (as a consumer) and to store-out (as a producer) electricity. The initial state of charge is predefined as $50 \%$ of full capacity. A constraint for a maximum or minimum limit to store-in or store-out per time unit is not considered in the model. As mentioned in the introductory part of this the chapter, e-mobility is implemented out of a system operators view. In other words, it is assumed as a storage system.

The specifications of the producing entities are implemented analogous to those of the consumption sector. Each generating entity has its own specific load profile. The generation of PV and wind depends on the nominal capacity of these power plants in combination with the local weather conditions regarding global radiation respectively wind speed. Thus, the characteristic fluctuating feed-in of these

\footnotetext{
${ }^{5}$ Please note that these screenshots are made before the simulation was started. Furthermore, both screenshots do not display the final state model, but a processing state.

${ }^{6}$ This assumption is based upon the mean value of the load profiles from ten different, comparable small- to medium-sized industry companies of eastern Germany.
} 
technologies is reflected. The feed-in of biomass and water is assumed as constant and adjustable. Costs are implemented as LCOE and variable costs of each generation unit.

Figure 5. Screenshot from the models interface

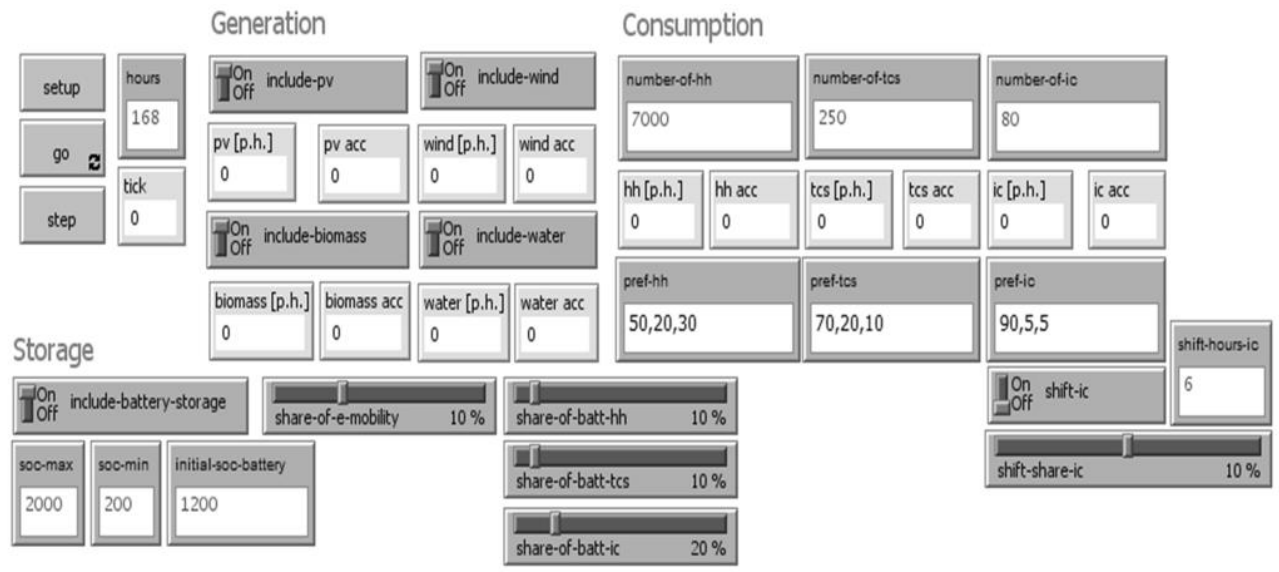

Source: Authors' own elaboration

Although the transmission grid entity plays a subordinate role in the model, it has two functions. First, compensating regional imbalances that cannot be stored respectively cannot be compensated by the storage systems. Second, provide the opportunity to supply those consumers with electricity who are not interested in being supplied regional from RES. In other words, this entity represents large conventional power plants, which are connected to the transmission grid, out of the models view. The distribution grid plays also a subordinate role. Both grids are implemented with no further constraints or limitations in the first stage. Constraints for the amount of electricity that can be transferred from the distribution to the transmission grid for compensating regional production overcapacity caused by a high share of RES will be a model extension. 


\section{Figure 6. Screenshot from the models entities}

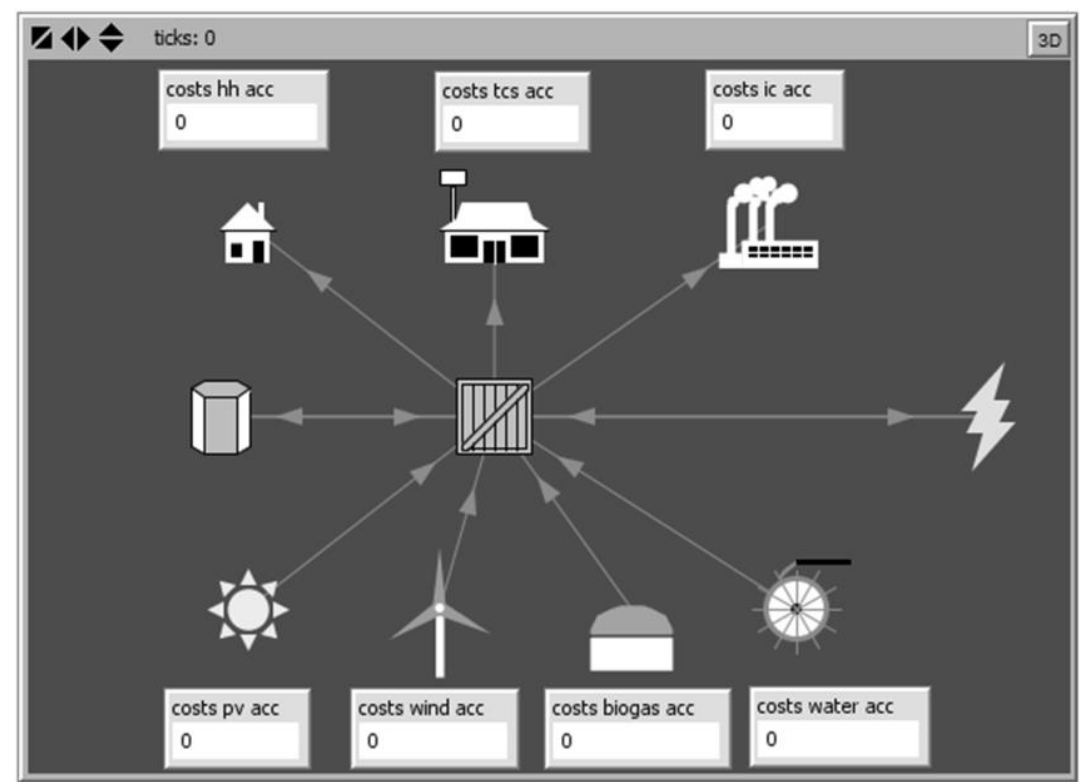

Source: Authors' own elaboration

\section{Conclusion}

Prices for electricity at the energy market are presently decreasing. In a paradoxical manner, electricity prices for consumers are increasing instead. This trend arises due to higher financial burdens causes by increasing shares of RES.

Despite a nationwide largely positive attitude to benefit from advantages of RES, opinions differ locally because of the local disadvantages for citizens. ${ }^{7}$ Achieving a high share of RES is therefore not only a technical issue, but also a question of public acceptance and the willingness to pay for it. Both are improvable by participation of citizens in a regional context (Walter et al. 2011; VDE 2015). Consumers will be one of the key factors for future supply systems. Their role in the energy market will change from passive to active.

\footnotetext{
${ }^{7}$ For example, noise pollution, blinking lights or impairment of landscape. For further information see
} (Schröter 2017: 6 f; Walter et al. 2011) 
The approach shown in this paper provides an alternative to considerations of energy supply systems via equation-based optimization models. By combining the $\mathrm{CA}$ with $\mathrm{ABM}$ it enhances to observe changing conditions of future supply systems concerning two central aspects of the German Energiewende, decentralisation and the consumers changing role into prosumers. This model will show whether regional energy markets will be beneficial to gain not only maximum profit for energy suppliers but also for increasing the personal value of the citizens.

The current legal situation in Germany is not aligned for regional trading of green electricity. This approach can offer a valuable contribution for rethinking and prove the usefulness of regional energy markets for a sustainable energy supply.

Based on the implemented price mechanism and the behaviour patterns of the consumers several impacts of future energy supply system concerning factors can be tested. It can be stated whether consumers can benefit from the current price situation and if their active role can be a leading incentive for increasing decentralisation and gaining high shares of RES. Furthermore, the model can provide insights how market outcome will change in the course of increasing shares of renewables and whether low or high shares are beneficial for short- and long-term self-financing of power plants based on RES. The model calculations might also explore whether regional trading of electricity would lead market participants to a more grid-friendly behaviour and if it would pose a valuable contribution to minimise grid expansion. 


\section{References}

AGEB (2016), Verteilung der Stromerzeugung aus Erneuerbaren Energien in Deutschland nach Energieträger im Jahr 2016 (Allocation of electricity generation from renewable energies in Germany among energy sources in 2016), https://de.statista.com/statistik/daten/studie/173871/umfrage/stromerzeugung-aus-erneuerbarenenergien-in-deutschland/ [04.09.2017].

BDEW (2016), Strompreis für Haushalte (Electricity price for households), https://www.bdew.de/internet.nsf/id/DC9ABD3F2D97604DC1257F42002E5075/\$file/160122\%20BD EW\%20zum\%20Strompreis\%20der\%20Haushalte\%20Anhang.pdf [20.11.2017].

BMWi (2015), Börsenstrompreis am EPEX-Spotmarkt in Deutschland in den Jahren 2010 bis 2016 (Electricity prices on EPEX spot market in Germany from 2010 to 2016), https://de.statista.com/statistik/daten/studie/154012/umfrage/grosshandelspreise-fuer-strom-indeutschland-seit-2008/ [20.11.2017].

BMWi (2016), Erneuerbare Energien in Zahlen - Nationale und internationale Entwicklung im Jahr 2015 (Renewable Energies in figures - national and international development in year 2015), https://www.bmwi.de/Redaktion/DE/Publikationen/Energie/erneuerbare-energien-in-zahlen-201509.pdf?_blob=publicationFile\&v=20 [04.09.2017].

Bundesnetzagentur, Bundeskartellamt (2016), Strompreise* für Haushaltskunden in Deutschland in den Jahren 2006 bis 2016 (Electricity prices for households in Germany from 2006 to 2016), https://de.statista.com/statistik/daten/studie/154908/umfrage/strompreise-fuer-haushaltskunden-seit2006/ [20.11.2017].

Bundesnetzagentur (2017), Ausschreibungen 2017 (Call for bids 2017), https://www.bundesnetzagentur.de/DE/Sachgebiete/ElektrizitaetundGas/Unternehmen_Institutionen/A usschreibungen/Solaranlagen/BeendeteAusschreibungen/Ausschreibungen2017/Ausschreibungen2017 _node.html [29.11.2017].

Bundesnetzagentur (2017), Beendete Ausschreibungen 2017 (Finished call for bits 2017), https://www.bundesnetzagentur.de/DE/Sachgebiete/ElektrizitaetundGas/Unternehmen_Institutionen/A usschreibungen/Wind_Onshore/BeendeteAusschreibungen/BeendeteAusschreibungen_node.html [29.11.2017].

Bundesnetzagentur (2017), Gebotstermin (Deadline for bids), https://www.bundesnetzagentur.de/DE/Sachgebiete/ElektrizitaetundGas/Unternehmen_Institutionen/A usschreibungen/Wind_Onshore/Gebotstermin_01_11_2017/Gebotstermin_01_11_17_node.html\#doc73 3142bodyText1 [29.11.2017].

$\begin{array}{lllll}\text { Bundesnetzagentur } & \text { (2017), } & \text { Netzausbau.de } & - & \text { FAQ, }\end{array}$ https://www.netzausbau.de/wissenswertes/faq/de.html [04.09. 2017].

Fraunhofer ISE (2016), Stromerzeugung in Deutschland in 2015 (Electricity generation in Germany in 2015), https://www.energy-charts.de/energy_pie_de.htm?year=2015 [ 05.09.2017]. 


\section{IMPACTS OF REGIONAL ENERGY MARKETS ON DECENTRALISED ENERGY SUPPLY}

Fraunhofer ISE (2017), Installierte Netto-Leistung zur Stromerzeugung in Deutschland (Installed net capacity for generation of electricity in Germany), https://www.energy-charts.de/power_inst_de.htm [05.09.2017].

Fraunhofer ISE (2017) Aktuelle Fakten zur Photovoltaik in Deutschland (Current facts about Photovoltaic in Germany), https://www.ise.fraunhofer.de/content/dam/ise/de/documents/publications/studies/aktuelle-fakten-zurphotovoltaik-in-deutschland.pdf [05.09.2017].

Genoese M. (2010), Energiewirtschaftliche Analysen des deutschen Strommarkts mit agentenbasierter Simulation (Energy-economical analysis of the German energy market via agent-based simulation), 1 ed, Karlsruhe, Nomos.

Grimm V. et al. (2006), A standard protocol for describing individual-based and agent-based models, "Ecological Modelling", vol. 15, pp. 115-126.

Hamill L., Gilbert N. (2016), Agent-Based Modelling in Economics, $1^{\text {st }}$ ed. Surrey, Wiley.

Howitt P. (2012), What have central bankers learned from modern macroeconomic theory?, "Journal of Macroeconomics", vol. 34, pp. 11-22.

KFW (2016), Kosten der Erneuerbaren Energien - Wie teuer ist der Ökostrom wirklich? (Costs of renewable energies - how expensive is green electricity in real?), https://www.kfw.de/PDF/DownloadCenter/Konzernthemen/Research/PDF-Dokumente-Fokus-Volkswirtschaft/Fokus-Nr.-145-Oktober2016-Kosten-EE-Ausbau.pdf [10.07.2017].

Kießling A. (2017), energycells.eu, http://www.energycells.eu/zellularer-ansatz [13.12. 2017].

Nintzel C. (2016), regev-rossdorf.de, https://www.regev-rossdorf.de/projekte/wkatannenkopf/artikelserie-windkraft-in-ro\%C3\%9Fdorf-stromnetz-und-stromhandel/ [13.04.2018].

Schröter F. (2017), Ziele der deutschen Wirtschafts- und Energiepolitik (Objectives of the German economic and energy policy), In: F. J. Matzen \& R. Tesch, eds. Industrielle Energiestrategie Praxishandbuch für Entscheider des produzierenden Gewerbes (Industrial energy strategy - practical handbook for decision-makers of the production industry), $1^{\text {st }}$ ed, Eschborn, Mainz, Springer Gabler, pp. 3-17.

Use My Energy (2017), Strompreisprognose (Electricity price forecast), Zittau, Use My Energy.

VDE (2015), Der Zellulare Ansatz - Grundlage einer erfolgreichen, regionenübergreifenden Energiewende (The Cellular Approach - Basis of a succesful, inter-regional Energy Turnaround), Frankfurt a.M.: Energietechnische Gesellschaft (ETG) im VDE.

Walter G., Krauter S., Schwenzer A. (2011), Erfolgsfaktoren für die Akzeptanz von ErneuerbareEnergie-Anlagen (Success factors for the acceptance of Renewable Energy power plants), „Energiewirtschaftliche Tagesfragen“, pp. 47-49. 